\title{
Lithic Raw Material Procurement in the Late Neolithic Southern-Transdanubian Region: A Case Study From the Site of Alsónyék-Bátaszék
}

\author{
Kata Szilágyi ${ }^{a}$
}

\begin{abstract}
This article summarizes the current state of research on the flaked stone assemblages from the Late Neolithic site Alsónyék-Bátaszék, Tolna district. The raw material distribution of the nearly 6Ioo pieces that make up the stone tool assemblage is the focus of this paper, with a particular emphasis placed on the dominance of the local raw material. The research addresses the question of the method of procurement of the lithic raw material in the case of this enormous, extended Neolithic site. To supply an answer, basic geoarchaeological research was necessary. To that end, a field survey aimed at detecting those geological formations and lithic variations convenient for knapping was undertaken. The results of the survey reported in the second part of this paper help in our understanding of the selection strategy of the ancient knapping specialists. From these strategies, it is possible to recognize the cultural tradition and raw material manipulation of this Late Neolithic community and, in a wider sense, the southeastern group of the Lengyel culture.
\end{abstract}

KEY-WORDS: Carpathian Basin, Transdanubia, Late Neolithic, Lengyel culture, Mecsek radiolarite, local raw material characteristics and distribution, field survey

\section{INTRODUCTION}

The site at Alsónyék-Bátaszék is located in south-eastern Transdanubia (in the southern part of Hungary, Tolna district). It is situated near the Danube River, the main natural artery of communication in the area, and at the meeting point of two different regions, the Transdanubian Hills and the Great Hungarian Plain (Fig. I). The emblematic sites of the Lengyel culture (Zengővárkony, Baranya district; Pécsvárad-Aranyhegy, Baranya district; Lengyel-Sánc, Tolna district; Mórágy-Tüzkődomb, Tolna district; and Villánykövesd, Baranya district) are also located nearby. The Lengyel settlement of Alsónyék is unique among the culture's known sites and represents a period of flourishing in its lifespan (Fig. 2).

a Móra Ferenc Museum, Szeged (Hungary); e-mail: szil.szvetlana@gmail.com; ORCID: 0000-0002-3944-995I 
I28 $\mid$ Szilágyi

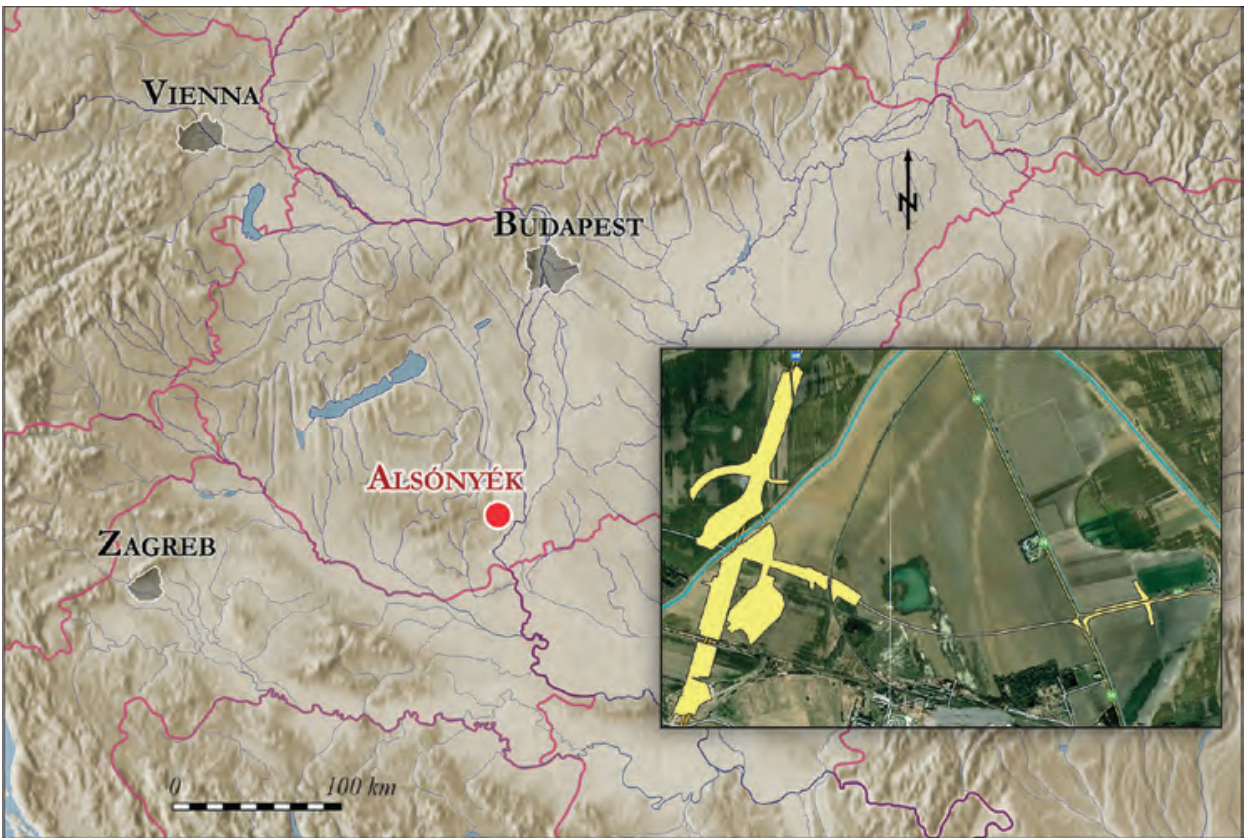

Fig. 1. Location of the Alsónyék-Bátaszék site (Tolna district) and outline plan of the excavation (Osztás et al., 2013a: Fig. 1.)

The 15,443 features uncovered in the $254,417 \mathrm{~m}^{2}$ area of the excavations reflect and provide evidence for intensive occupation at the site (Osztás et al., 2013a: 18). In addition to several later periods, traces of inhabitation were found belonging to cultures which cover almost the entire duration of the Neolithic in the region (Starčevo culture, Central European Linearbandkeramik [LBK], Sopot culture and Lengyel culture). The traces of Lengyel occupation can be seen over the entire excavated area (Gallina et al., 2010: 7; Osztás et al., 2012: 377-378; Osztás et al., 2013b: 180). Nearly 9000 of the almost 15,000 features can be assigned to the Lengyel culture, including 2300 burials, hundreds of pits, and at least I22 post-framed houses.

Alsónyék is a very important site in the Neolithic period in Hungary, as no other Neolithic site yet excavated has contained such a number of burials and post-framed houses (Osztás et al., 2013b: 182). According to the relative chronology of the region, the site belongs to Lengyel II. As part of the TOTL [The times of their lives: towards precise narratives of change in the European Neolithic through formal chronological modelling] project, the opportunity was provided to absolutely date the site using the radiocarbon method. Altogether, 2I7 radiocarbon results pertain to the Lengyel phase. The burial activity probably began around $4710-4685$ cal BC ( $95 \%$ probability); $4715-4690 \mathrm{cal}$ BC (68\% probability) and the settlement was established in $4735-4695 \mathrm{cal} \mathrm{BC}(95 \%$ prob- 


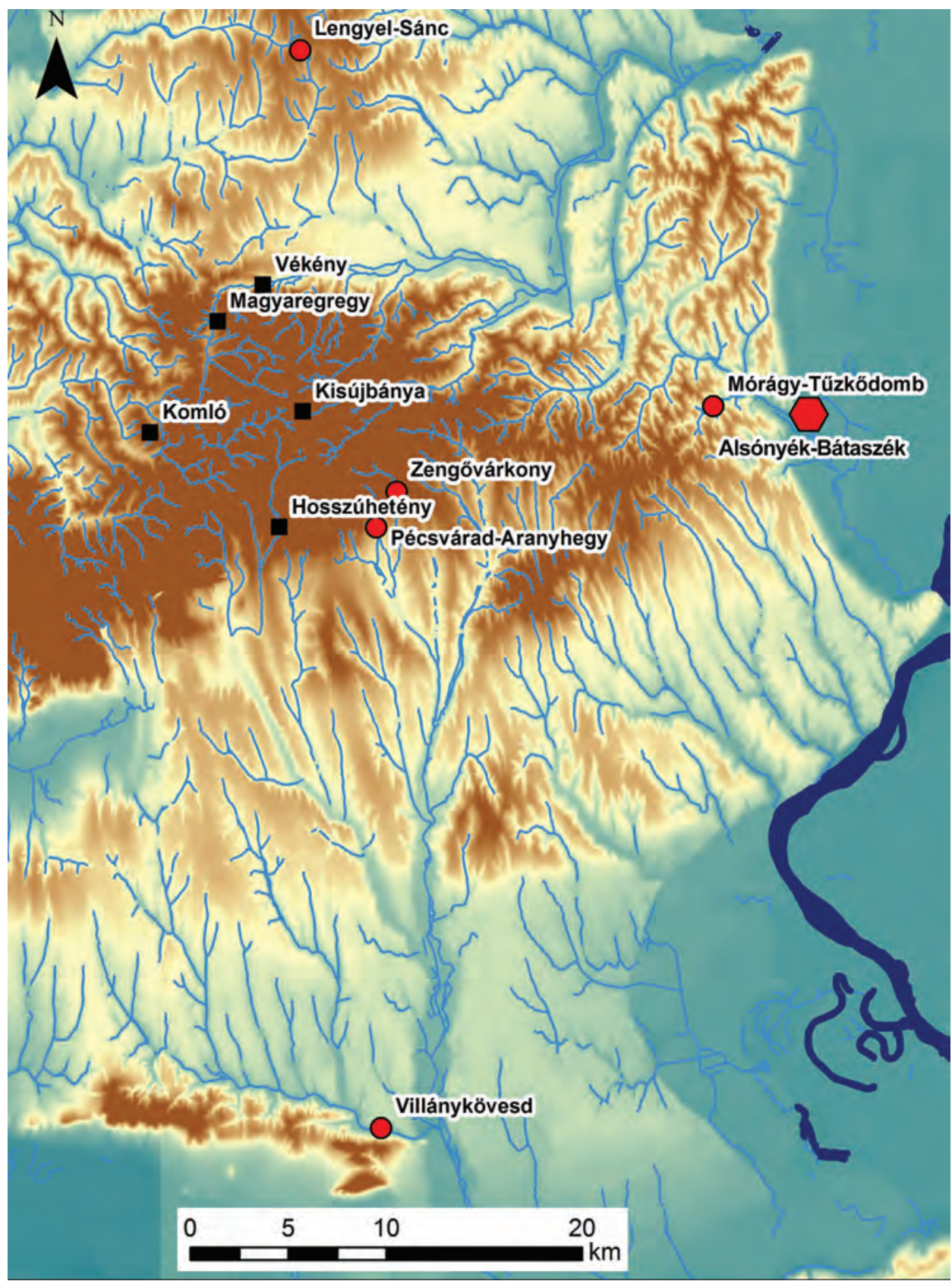

Fig. 2. Location of Alsónyék-Bátaszék (Tolna district) and major sites of Lengyel culture's South-Eastern Transdanubian group: black squares - Geological sources of Mecsek radiolarite; red dots - important sites; red hexagon - Alsónyék-Bátaszék). Computer graphics: P. Czukor. 
I30 $\mid$ Szilágyi

\section{RAW MATERIAL STRUCTURE OF THE SETTLEMENT}

$(\mathrm{N}=\mathbf{4 8 2 7})$
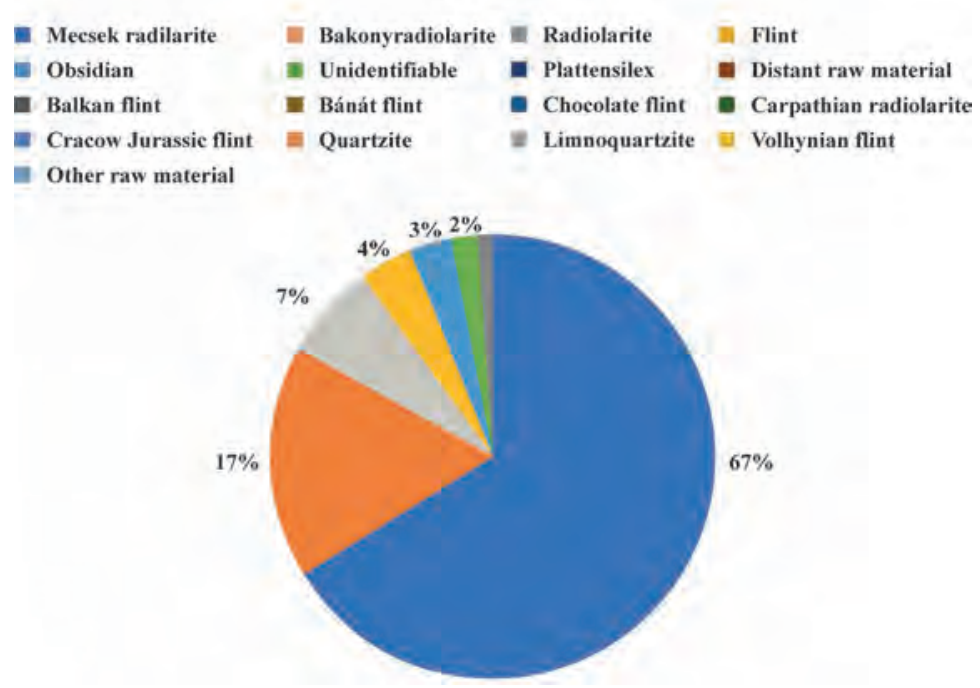

Fig. 3.1. Raw material structure of the settlement at the site Alsónyék-Bátaszék (Tolna district). Computer graphics: K. Szilágyi.

\section{RAW MATERIAL STRUCTURE OF THE BURIALS}

$(\mathrm{N}=1279)$
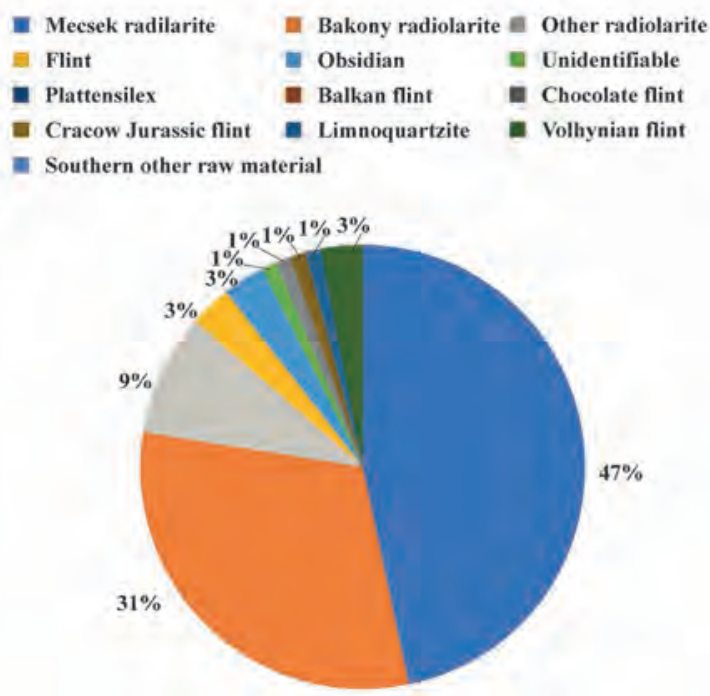

Fig. 3.2. Raw material structure of the burials at the site Alsónyék-Bátaszék (Tolna district). Computer graphics: K. Szilágyi. 
Lithic Raw Material Procurement in the Late Neolithic Southern-Transdanubian Region $\mid$ I3I

ability); 4720-4700 cal BC (68\% probability) in Alsónyék-Kanizsa-dűlő. Burial activity ended ca. $4705-4640 \mathrm{cal} \mathrm{BC}$ (95\% probability); $4695-4670 \mathrm{cal} \mathrm{BC} \mathrm{(68 \%} \mathrm{probability)} \mathrm{and}$ the Lengyel settlement ended around 4715-4680 cal BC (95\% probability); 4695-4670 cal BC (68\% probability; Osztás et al., 2013b: 212-220, 222-224).

\section{MATERIAL AND METHODS}

\section{Lithic assemblage}

The entire flaked stone assemblage contains 6106 pieces (including stray finds). The majority of the stone tools came from well-defined archaeological features, mainly pits in the part of the site that was a settlement ( 4827 items, 79.05\%). Within this settlement assemblage, the flaked stone tools derive almost exclusively from the occupation at Alsónyék-Kanizsa-dűlő (northern part of the excavation), the area where most of the timber-framed buildings are located (Szilágyi 2017a: 65-69). In addition to these settlement finds, nearly one quarter $(20.95 \%$, I279 pieces) of the stone tool assemblage was discovered in burials across the site. As most of the burials (grave groups) are also clustered in the northern part of the site, in general flaked stone tools were found more frequently in the northern part of the excavation (Szilágyi 20I7b: 104-IO5). Due to the density of archaeological features and the amount of the stone tools, we thus created the processing methods for material from the northern part of the excavation and applied them systematically to the rest of the site.

\section{The raw material structure}

\section{Settlement}

The raw material structure is relatively homogeneous; two kinds of radiolarite predominate (4037 items, 83.64\%). One type is Mecsek radiolarite (3237 items, 67.06\%), and the other is Bakony radiolarite (800 items, $16.58 \%$ ). These kinds of radiolarite are suitable for knapping because they are both very homogeneous materials. Other radiolarites and flints were grouped into more general lithic groups as the pieces lacked markers that would allow a more exact provenience determination. Raw-materials coming from a farther distance include Obsidian, Plattensilex (Plattensilex/AbensbergArnhofen type hornstone; Binsteiner 2005), Balkan flint, Bánát flint, 'chocolate' flint, Carpathian radiolarite, Jurassic-Cracow flint and Volhynian flint. Five pieces were identified as coming from a non-local raw material where the exact provenience could not be determined, though an origin in the southern part of the Balkans is likely. Altogether, flaked stone tools made of more non-local raw materials were relatively uncommon in the assemblage ( 150 items, 3.10\%). The presence of Plattensilex is very interesting as only one piece is known in the south-Transdanubian Lengyel culture so far, coming from Mórágy-Tűzkődomb, Tolna district (Zalai-Gaál 2009; Fig. 3:I). 
I32 $\mid$ Szilágyi

\section{Burials}

Nearly a half of the stone tools found in burial contexts were made from Mecsek radiolarite (596 items, 46.6\%); Bakony radiolarite variants were also included in larger quantities (397 items, 31.04\%). It was not possible to determine the exact raw material source (e.g. mountain range of origin) of II 2 examples of radiolarite and 43 examples of flint tools; thus, a single miscellaneous radiolarite and one similar flint lithic group were defined. Of the tools made from more non-local raw materials, Obsidian, Plattensilex, Balkan flint, 'chocolate' flint, Jurassic-Cracow flint, Volhynian flint and raw material of a southern origin (perhaps Balkan, like in the case of the settlement) occurred in relatively small numbers. Among these, Volhynian flint was found in the largest quantity. The number of pieces made of non-local raw material (95 items, $7.43 \%$ ) is less than in the settlement, but the proportion in relation to tools of local raw materials is much higher than in the settlement assemblage (Fig. 3.2).

\section{Raw material supply zones}

\section{Local supply zone}

Mecsek radiolarite was formed during the Upper Jurassic-Lower Cretaceous period. Macroscopically, the colors of Mecsek radiolarite are very varied, with colours ranging from lilac-brown to silky greenish-blue grey. These colour variations can often occur in a single core, thereby making recognition of related items difficult. The Mecsek radiolarites are typically silky, which distinguishes them from the more brightly colored Bakony radiolarites. Mecsek radiolarite has a rough cortex that is relatively thin ( $-3 \mathrm{~mm}$ ) and sharply separated from the radiolarite. Geological sources of Mecsek radiolarite are known from Komló, Magyaregregy, Kisújbánya, Hosszúhetény and Vékény, Baranya district. The source of the Mecsek radiolarite is within the local supply zone for Alsónyék-Bátaszék; it is in the eastern part of the Mecsek Mountains, I5-30 km from the site (Bácskay and Biró 1984; Barabás 1986; Konda 1986; Biró 1988, 1989, 1990, 1998; Fig. 4).

\section{Regional supply zones}

Bakony radiolarites are one of the most important raw materials for the territory west of the Danube River. Bakony radiolarites were formed during the Middle and Upper Jurassic periods. These radiolarites are characterized by fine granularity, vivid colours and a creamy white to whitish-yellow cortex (porcelanites). The cortexes are also homogenous in texture. The colour of the Bakony radiolarite is also varied with orange-red, orange-brown, yellowish-brown, mustard and dark brown shades known. The primary geological sources lie in the Jurassic limestone of the Bakony Mountains to the north of Lake Balaton. The source of the Bakony radiolarite variations defines the regional supply zone for Alsónyék-Bátaszék; in the southern part of the Bakony Mountains, the source is $180-200 \mathrm{~km}$ from the settlement (Biró 1998; Mateiciucová 2008). 


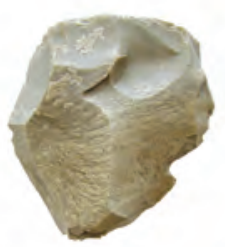

(1)

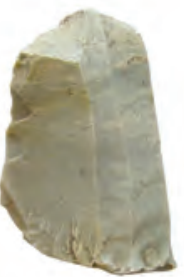

(6)

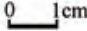

$\underbrace{0.1 \mathrm{~cm}}$

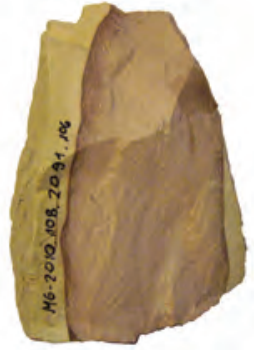

(7)

(2)

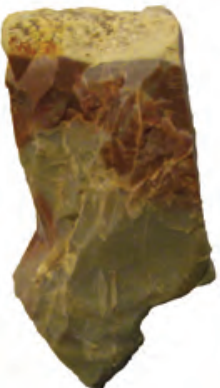

(3)

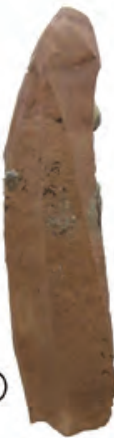

(4)
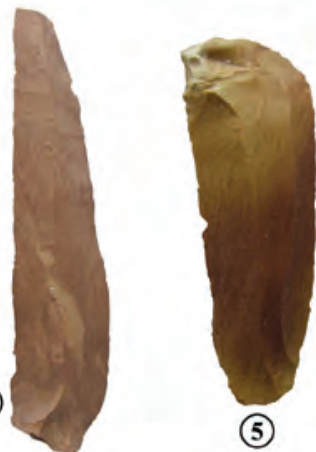

(5)

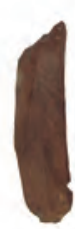

(9)

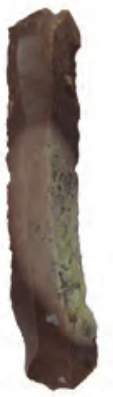

(10)

Fig. 4. Stone tools from Mecsek radiolarite at the site Alsónyék-Bátaszék, Tolna district. 1 - retouched flake; 2 - raw material block; 6-7 - cores; 3-5 and 8-10 - blades. Computer graphics: P. Czukor.

The appearance of limnoquartzites is quite varied within one geological source, thus their identification is more difficult than that of radiolarites. There are transparent and translucent variants as well as a wide range of colours (white, bluish-white, bluish-grey, yellowish-brown and yellowish-grey). Six pieces of limnoquartzite may come from the Mátra Mountains, placing them within the regional supply zone as well. The limnoquartzite may have come from the Mecsek Mountains, but further instrumental investigation is necessary to verify this (Biró and Dobosi, I99I; Biró et al., 2000).

\section{Distant supply zones}

Given the number of different non-local raw materials found at Alsónyék-Bátaszék and the availability of extensive, detailed literature concerning their properties and geological sources, these issues will not be discussed here. The sources of these raw materials reflect distant supply zones, 600-800 km away (Kaczanowska 1985; Pelisiak 1987; Mateiciucová 2008; Gurova 20II; Přichystal 20I3; Szilágyi 20I7a: 70-7I and Fig. 7). 
I34 Szilágyi

\section{RESULTS}

\section{The field survey in the East-Mecsek Mountains}

In 2017 a new geoarcheological research project was started in the eastern part of the Mecsek Mountains (East-Mecsek), focused on determining the exact geological sources of the local radiolarite. The main aim of the project was to find and document the knappable raw materials in this region. Emphasis was placed on materials present in the flaked stone assemblage of the southeast-Transdanubian group of the Late Neolithic Lengyel culture. The Alsónyék site and its flaked stone collection was taken as a starting point in characterizing this larger assemblage.

The first step taken by the project was the collection and digitalization of the drift and solid geology geological maps of East-Mecsek. The second stage was to review the comparative raw material collections in the Hungarian National Museum in Budapest and the Komló City Museum. In the study of these collections we focused on the Jurassic and Cretaceous geological formations.

\section{The documenting and sampling strategy}

In maps digitalized during the first stage of research, Jurassic and Cretaceous formations were identified on the surface over quite a large territory. This area stretches from Komló to Ófalu (Baranya district) west to east and from Kárász (Baranya district) to Pécsvárad north to south. We started the field survey in valleys which contained the most formations according to these maps. The area of research was delineated according to the following three factors:

I. Selection of the formations belonging to the Jurassic and Cretaceous periods

2. Starting with larger formations on the surface

3. Starting with formations that have been previously studied and published.

The systematic field survey was started where these factors were most prevalent. At a later stage, the field investigation was continued in areas where the least information was available. All in all, the project was started with entire stream valleys that could have had a similar morphology in prehistoric times to that which they have in the present day.

Four limestone formations, one calcareous marl (Raucsik 20I2b: 174-176), and one sandstone formation (Raucsik 20I2d: 159-163) were selected for investigation in the first field survey. The raw materials of interest in the Márévár (Gyalog 1996: IO4), Kisújbánya (Gyalog 1996: 107), Fonyászó (Raucsik 20I2a: I80-183) and Óbánya Limestone Formations (Raucsik 20I2c: 177-I79) were formed in the Middle Jurassic and Upper Jurassic period. These raw materials have different natural forms, colours (both shade and lightness), textures, and cortexes.

During this first survey, many debris exposures with flint and radiolarite in pebble, block, and layer form were found. Reconnaissance maps that could be integrated into the database created in the first steps of the project were always made. For each point of interest, 
photos and samples were taken and the same information was recorded: type of observation (e.g. source rock, outcrop), field notes (other points of interest in the area), and other comments (e.g. radiolarite intercalations, tectonic information kind, post-deposition effects).

After these first stages of the project, the research area was defined in space and time. From the preliminary results it was determined that the Jurassic and Cretaceous periods were the most important. The relevant geological maps were examined and information about the raw materials deposited during these periods was collected.

Nodules and lenses of flint are mainly characteristics of the Oxfordian and Titon-Berriazian formations. The latter formations, however, are very varied in the Mecsek Mountains. Thus, macroscopically observable silica concentrations are missing in several cases; the limestone contains silica in a dispersed distribution. In the Mecsek Mountains, the upper parts of the Titon-Berriazian formations have almost no flint lenses and where flint nodules are found, they are dominated by cortex. In contrast, the lower parts of these formations can be quite rich in flint.

\section{DISCUSSION}

The I22 points of interest identified during the field survey resulted in the collection of 258 geological samples. The reconnaissance maps and field documentation were recorded and analyzed in ArcGIS. In this way, both the maps and information collected in the archives as well as the results of the field survey were integrated geospatially (Fig. 5).

It is assumed that knapping specialists made a conscious choice in selecting the appropriate geological sources for their raw material depending on what types of tools they wanted to create. The lithic raw materials played an important role in the organization of technology. It is apparent that raw material availability, size, and quality had complex influences on different aspects of stone tool technology. This fact alone makes lithic raw material an important resource for gaining insight into human land use and mobility patterns in relation to lithic technology (Andrefsky 2008, 2009).

Currently, only Raman spectroscopy was employed to analyse some of the geological and archaeological samples. This is a non-destructive phase analytical tool which is a very effective method for analyzing the mineral composition of an archaeological sample. The aim of the application of this analytical method in relation to the research goals of this project was to examine the similarities between two kinds of samples - modern (geological) and prehistoric (archaeological). This method allows the investigation of the question if the samples collected from geological formations during our field survey represent the same sources as those used by the prehistoric knappers. The results of this analysis show that the geological and archaeological samples are very similar. The amount of moganite (cryptocrystalline $\mathrm{SiO}_{2}$ ) and minor carbonate in chert samples from geological and archaeological finds was similar. Thus, the moganite and carbonate content can 
136 Szilágyi

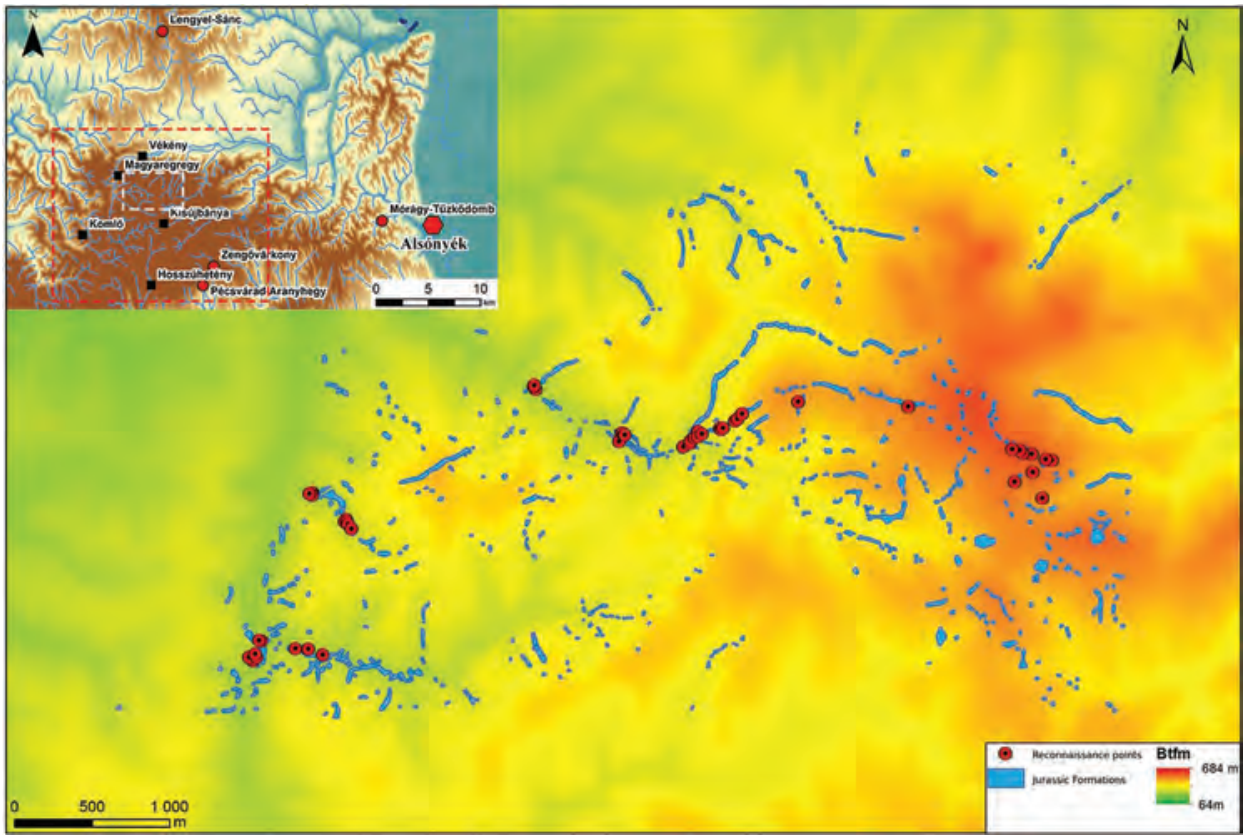

Fig. 5. The map of the microregion of the East-Mecsek geoarcheological project.

Computer graphics: P. Czukor.

be a discrimination marker during comparison of different finds with each other or with geological samples (Fig. 6). The next step of the geological research will be to create thin sections and analyze the geochemical components of the samples.

\section{CONCLUSION}

During field surveys, many quarries with radiolarite in the form of pebbles and blocks were found in East Mecsek. The petrographic formations and exact time of the genesis of these quarries were determined. It is supposed that toolmaking occurred throughout the settlement of Alsónyék. The local Mecsek radiolarite was of good quality and available in sufficient quantities for use. Most likely knapping specialists consciously chose the appropriate geological sources depending on what type of artefacts they wanted to create. The field investigation suggests that stream valleys were a good potential source of raw material, with an abundance of radiolarite pebbles. These pebbles are a secondary autochthonous source, thus the gatherer/knapper could collect the radiolarite pebbles fairly easily (Odell 2006), without pursuing the mining or digging activities needed in the case of the bedrock of the Bakony Mountains. However, the size of the 

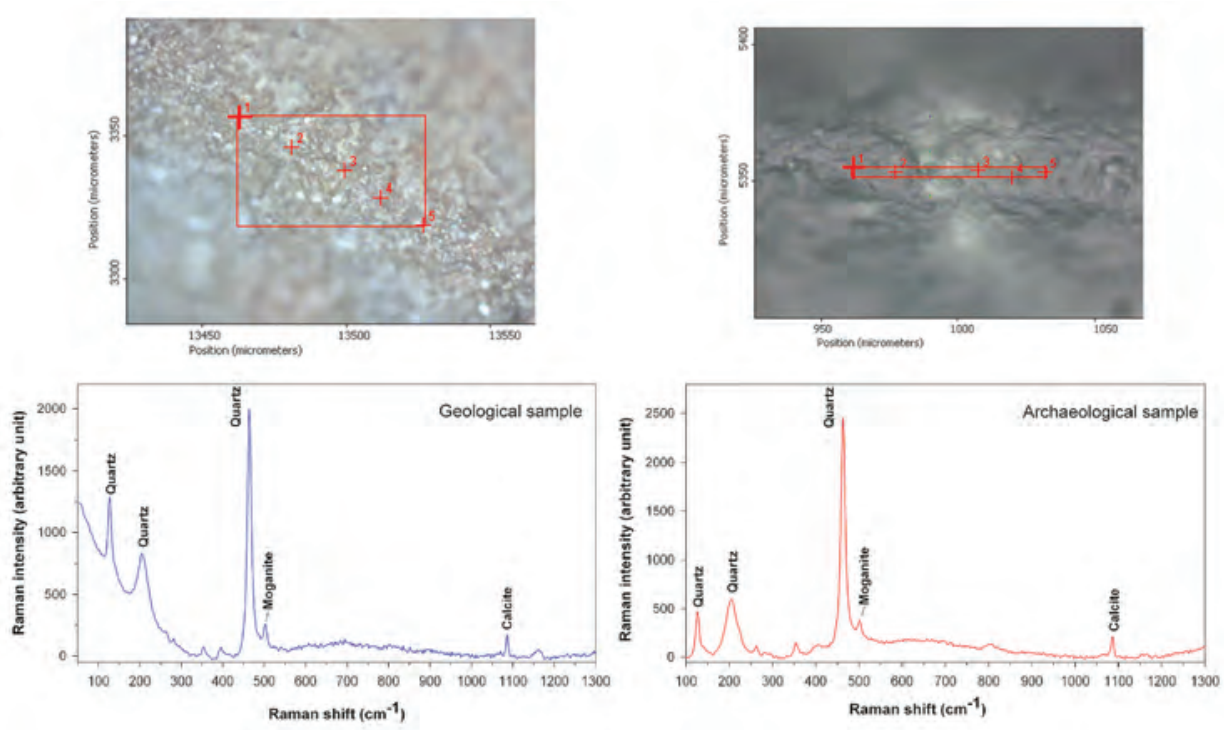

Fig. 6. The result of Raman spectroscopy. Computer graphics: K. Fintor.

pebbles was limited. Therefore, for the making of long blades, the knappers likely would have searched the bedrock (lining the stream valleys) where large radiolarite blocks were found during our field investigation, and again were saved the trouble of engaging in mining or digging activities as in the case of the Bakony Mountains. All in all, Mecsek radiolarite was probably collected continuously and this activity did not demand bigger expeditions. The farming communities settled generally some distance from the geological sources of the lithic raw materials.

Based on the distribution of the raw material, the Late Neolithic community at Alsónyék had very strong local networks. In the enormous settlement area with its the large number of features and finds, the lithics assemblage does not show evidence of widespread, intercultural networks. In contrast, imported tools from non-local raw material were found in some graves. At the current level of the research, it is possible to make some distinctions about the role of the manipulation of raw material. Everyday tools seem to have been made from local and regional raw materials. The more unique tools (i.e., long blades) were made from raw materials from more distant sources and were deposited in burials, suggesting such artefacts were an important element of the burial practice. In order to be able to interpret the entire raw material usage at Alsónyék and at a larger scale in southern-Transdanubia, it is a primary necessity to know the source of the raw material and how it was procured. All in all, the geoarcheological research on the Mecsek radiolarite (especial large-scale analytical studies) will be very important in the coming years. 

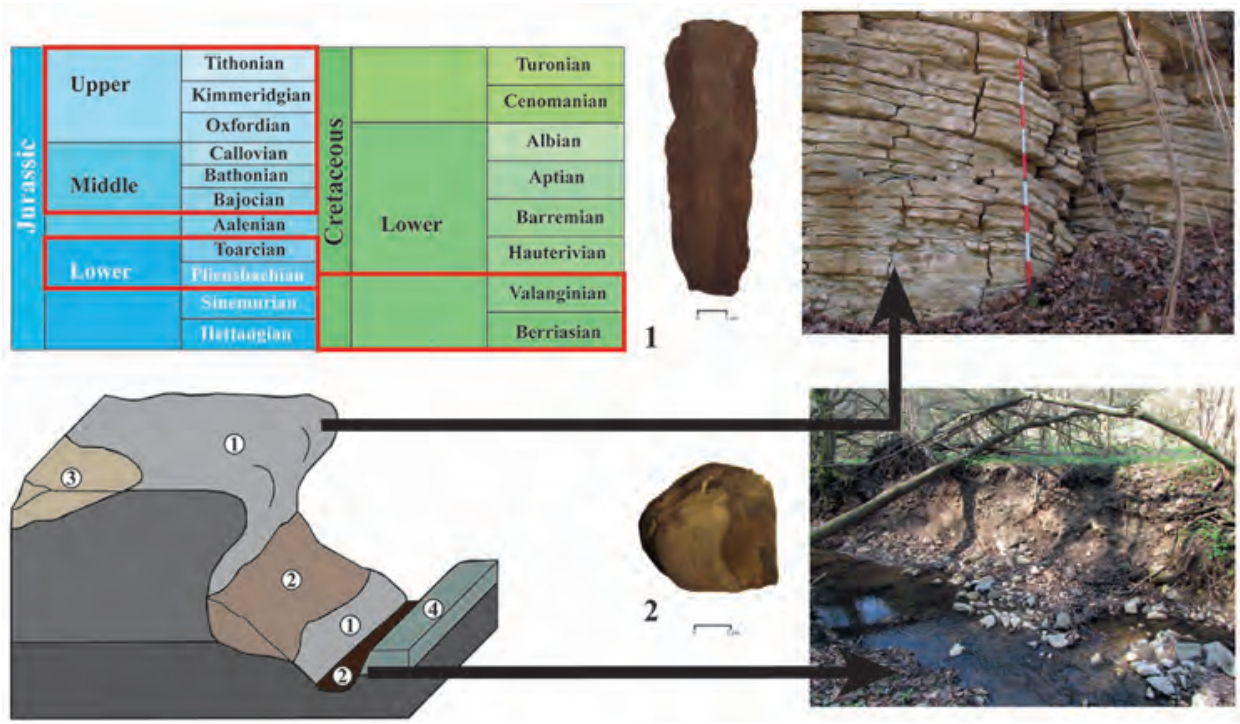

Fig. 7. Sources of different types of raw material (after Mester 2013: Fig. 4.):

The red rectangles show those time periods which contain suitable knappable raw materials. The two possible raw material procurement strategies: 1 - primary autochthonous source - bedrocks - large blade from the burial; 2 - secondary autochthonous source - stream bed - average sized core from the settlement. Computer graphics: K. Szilágyi.

\section{ACKNOWLEDGEMENTS}

I would like to thank the organizers Dagmara H. Werra and her colleagues for the opportunity to publish in this volume. I am indebted to Peter Czukor for the creation of the maps. I would also like to thank Dr. Krisztián Fintor (University of Szeged, Faculty of Science and Informatics, Department of Mineralogy, Geochemistry and Petrology) who helped me in the field survey and made the Raman spectroscopy analysis. I am grateful to Sarah Martini, who did the English language correction. The writing of this article was supported by the National Talent Program (NTP-NFTÖ-16-0858: 'Multidisciplinary prehistoric archaeological research in the region of East Mecsek Mountain').

\section{REFERENCES}

Andrefsky, W. JR. 2008. Lithic technology: measures of production, use, and curation. Cambridge, Cambridge University Press.

Andrefsky, W. JR. 2009. The Analysis of Stone Tool Procurement, Production, and Maintenance. Journal of Archaeological Research 17: 65-103. 
Bácskay, E. and Biró, K.T. 1984. A lengyeli lelőhely pattintott kőeszközeiről. Béri Balogh Ádám Múzeum Évönyve I2: 43-67.

Barabás, A. 1986. Upper Jurassic-Lower cretaceous Radiolaria from the Mecsek Mts. In Öskori kovabányászat és köeszköznyersanyag-azonositás a Kárpát-medencében. I. kötet/International conference on prehistoric flint mining and lithic raw material identification in the Carpathian Basin., I3I-I4O. Budapest, Sümeg Papers (Vol. I.), KMI Rota.

Binsteiner, A. 2005. Die Lagerstätten und der Abbau bayerischer Jurahornsteine sowie deren Distribution im Neolithikum Mittel- und Osteuropas. Jahrbuch des Römisch-Germanischen Zentralmuseums 52: 43-I55.

Biró, K.T. 1988. Distribution of lithic raw materials on prehistoric sites. Acta Archaeologica Academiae Scientiarum Hungaricae 40: 25I-274.

Biró, K.T. 1989. A lengyeli kultúra dél-dunántúli kőeszköz-leletanyagainak nyersanyagáról I. - On the Raw Material of the Chipped Stone Industry of South-Transdanubian Lengyel-Culture sites. Communicationes Archaeologicae Hungariae 4: 22-3I.

Biró, K.T. 1990. A lengyeli kultúra dél-dunántúli kőeszköz-leletanyagainak nyersanyagáról II. - On the Raw Material of the Chipped Stone Industry of South-Transdanubian Lengyel-Culture sites. Communicationes Archaeologicae Hungariae 42: 66-76.

Biró, K.T. 1998. Lithic implements and the circulation of the raw materials in the Great Hungarian Plain during the Late Neolithic Period. Budapest.

Biró, K.T. and Dobosi, V.T. 1991. Litotheca - comparative raw material collection of the Hungarian National Museum. Catalogue. Budapest, Hungarian National Museum.

Biró, K.T., Dobosi, V.T. and Schléder, Zs. 200o. Litotheca II - comparative raw material collection of the Hungarian National Museum 1990-1997. Catalogue. Budapest, Hungarian National Museum.

Gallina, Zs., Hornok, P., Paluch, T. and Somogyi, K. 20ıо. Elözetes jelentés az M6 AP TO ıо/B és ir. számú lelőhelyrészen végzett megelőző feltárásról. Alsónyék-Bátaszék (Tolna megye) 2006-2009. Wosinsky Mór Múzeum Évkönyve 32: 7-46.

Gurova, M. 20II. Prehistoric flint assemblages from Bulgaria: A raw material perspectives. In Orient şi Occident/East and West. Cultură şi civilizație la Dunărea de jos XXVIII/Culture and Civilization at the Lower Danube, 96-IIs. Călăraşi.

Gyalog, L. (ed.) 1996. A földtani térképek jelkulcsa és a rétegtani egységek rövid leírása. Budapest, Magyar Állami Földtani Intézet.

Kaczanowska, M. 1985. Rochstoffe, Technik und Typologie der neolithischen Feuersteinindustrien im Nordtei des Flussgebietes der Mitteldonau. Warszawa, Państwowe Wydawnictwo Naukowe.

Konda, J. 1986. The Mezozoic siliceous rocks of the Transdanubian Mid-Mountains. In Öskori kovabányászat és köeszköznyersanyag-azonositás a Kárpát-medencében. I. kötet/International conference on prehistoric flint mining and lithic raw material identification in the Carpathian Basin. Sümeg Papers (Vol. I), I65-I68. Budapest, KMI Rota.

Mateiciucová, I. 2008. Talking Stones: The chipped stone industry in Lower Austria and Moravia and the Beginnings of the Neolithic in Central Europe (LBK) 5700-4900 BC. Brno, Dissertationes Archaeologicae Brunensis.

Mester, Zs. 20I3. The lithic raw material sources and interregional human contacts in the Northern Carpathian regions: Aim and methodology. In Zs. Mester (ed.), The lithic raw material and interregional human contacts in the Northern Carpathian regions, 9-22. Kraków-Budapest.

Odell, G.H. 2006. Lithic Analysis. Oklahoma, University of Tulsa.

Osztás, A., Zalai-Gaál, I. and Bánffy, E. 20I2. Alsónyék - Bátaszék: a new chapter in the research of the Lengyel culture. Documenta Praehistorica 39: 377-396. 
I40 $\mid$ Szilágyi

Osztás, A., Bánffy, E., Zalai-Gaál, I., Oross, K., Marton, T. and Somogyi, K. 2orza. Alsónyék-Bátaszék: introduction to a major Neolithic settlement complex in south-east Transdanubia, Hungary. Bericht der Römisch-Germanischen Kommission 94: 7-22.

Osztás, A., Zalai-Gaál, I., Bánffy, E., Marton, T., Nyerges, É., Köhler, K., Somogyi, K., Gallina, Zs., Bronk Ramsey, C., Dunbar, E., Kromer, B., Bayliss, A., Hamilton, D. and Whittle, A. 20rzb. Coalescent community at Alsónyék: the timings and duration of Lengyel burials and settlement. Bericht der Römisch-Germanischen Kommission 94: 180-36I.

Pelisiak, A. 1987. The flint raw material from the Central part of the Polish Jura and its utilisation in prehistory. In Öskori kovabányászat és köeszköznnyersanyag-azonositás a Kárpát-medencében. 2. kötet। International conference on prehistoric flint mining and lithic raw material identification in the Carpathian Basin. Sümeg Papers (Vol. 2), I23-I37. Budapest, KMI Rota.

Přichystal, A. 2013. Lithic raw materials in Prehistoric Times of Eastern Central Europe. Brno, Masaryk University.

Raucsik, B. 20I2a. Fonyászói Mészkő Formáció. In I. Fózy (ed.), Magyarország litosztratigráfiai alapegységei. Jura, I80-183. Budapest, Magyarhoni Földtani Társulat.

Raucsik, B. 2oı2b. Komlói Mészmárga Formáció. In I. Fózy (ed.), Magyarország litosztratigráfiai alapegységei. Jura, 174-176. Budapest, Magyarhoni Földtani Társulat.

Raucsik, B. 20I2c. Óbányai Mészkő Formáció. In I. Fózy (ed.), Magyarország litosztratigráfiai alapegységei. Jura, I77-179. Budapest, Magyarhoni Földtani Társulat.

Raucsik, B. 20I2d. Mecseknádasdi Homokkő Formáció. In I. Fózy (ed.), Magyarország litosztratigráfiai alapegységei. Jura, 159-163. Budapest, Magyarhoni Földtani Társulat.

Szilágyi, K. 20I7a. Approaching household units from chipped stone assemblages at Alsónyék-Bátaszék, south Hungary. Bulgarian e-Journal of Archaeology 7: 6I-83.

Szilágyi, K. 20I7b. Preliminary result of the lithic raw material distribution at the Alsónyék-Bátaszék Late Neolithic site (Southeastern Hungary). In S. Forțiu (ed.), Archeovest $V_{I}-$ In honorem Doina Benea - Interdisciplinaritate in Arheologie si Istorie, 99-I29. Szeged, JATEPress Szeged.

Zalai-Gaál, I. 2009. Zur Herkunft des Schädelkults im Neolithikum des Karpatenbeckens. Budapest, Archaeolingua. 